\title{
KORELASI KARAKTERISTIK EKOLOGI TEMPAT PERINDUKAN VEKTOR MALARIA DENGAN KEPADATAN LARVA Anopheles Spp DI DESA HANURA KABUPATEN PESAWARAN PROVINSI LAMPUNG
}

\author{
Devita Febriani Putri ${ }^{1}$, Ismalia Husna' ${ }^{1}$, Dessy Hermawan ${ }^{2}$, Firmansyah ${ }^{3}$
}

${ }^{1}$ Departemen Parasitologi Fakultas Kedokteran Universitas Malahayati

2]urusan Keperawatan Fakultas Kedokteran Universitas Malahayati

${ }^{3}$ Program Studi Kedokteran Fakultas Kedokteran Universitas Malahayati

[email korespondensi: devita@malahayati.ac.id]

\begin{abstract}
Correlation of Ecological Characteristics Of Malaria Vector Density With Anopheles Spp Larva Density In Hanura Village, Pesawaran District, Lampung Province. Malaria is an infectious disease transmitted by female Anopheles sp. Mosquitoes. Based on the Health Profile of Pesawaran District, it is known that there were 3,123 malaria cases. Positive cases of malaria only occurred in 3 working areas of the health center, namely Hanura Health Center $(2,528$ cases $)$, Pesawaran District was a malaria endemic area because of its natural conditions. Objective to determine the correlation between the ecological characteristics of the breeding sites for malaria vectors and the density of Anopheles spp. larvae in Hanura Village, Pesawaran Regency, 2019. This type of research is quantitative, descriptive analytic design with cross sectional approach. The population of all potential breeding places for mosquitoes is 3 locations. Samples were 3 locations with purposive sampling technique. Retrieval of data using the observation sheet. The data analysis technique used the Pearson statistical test. Results of this research were the chemical environment where Anopheles spp malaria vector breeds in Hanura Village has an average water $\mathrm{pH}$ of 7.67, an average water salinity of $3.47 \%$, and an average dissolved oxygen (DO) of $2.7 \mathrm{mg} / \mathrm{L}$. The physical environment where the Anopheles spp malaria vector breeds in Hanura Village has an average water temperature of $28.25^{\circ} \mathrm{C}$ and an average water depth of $85 \mathrm{~cm}$. Biological environment where Anopheles spp malaria vector breeds in Hanura Village with the discovery of mangrove, moss, coconut and fish, crab, snail, shrimp and tadpole species. The density of Anopheles spp mosquito larvae in Hanura Village was 10.08. Conclusion of this research were the chemical, physical and biological environment correlated with the density of Anopheles spp mosquito larvae in the village of Sukajaya Lempasing with water $\mathrm{pH}$ $(p=0.031, r=-0.622)$, water salinity $(p=0.085, r=0.517)$, oxygen content ( $p$ $=0.020, r=-0.657)$, temperature $(p=0.021, r=-0.655)$, depth $(p=0.000, r=$ $-0.872)$, plants $(p=0.000, r=0.878)$ and animals $(p=0.056, r=-0.563)$. The community is advised to eradicate mosquito breeding sites by spreading larvaeeating fish seeds.
\end{abstract}

Keywords: Ecology, Brooding, Vector, Larva, Anopheles spp

\begin{abstract}
Abstrak : Korelasi Karakteristik Ekologi Tempat Perindukan Vektor Malaria Dengan Kepadatan Larva Anopheles Spp Di Desa Hanura Kabupaten Pesawaran Provinsi Lampung. Malaria adalah salah satu penyakit infeksi yang ditularkan oleh nyamuk Anopheles $s p$ betina. Berdasarkan Profil Kesehatan Kabupaten Pesawaran diketahui bahwa terdapat sebanyak 3.123 kasus malaria. Kasus positif malaria hanya terjadi di 3 wilayah kerja puskesmas yaitu Puskesmas Hanura (2.528 kasus), Kabupaten Pesawaran menjadi daerah yang endemis malaria karena kondisi alamnya. Tujuan penelitian diketahui korelasi karakteristik ekologi tempat perindukan vektor malaria dengan kepadatan larva Anopheles spp. di Desa Hanura Kabupaten Pesawaran Tahun 2019. Jenis penelitian kuantitatif,
\end{abstract}


rancangan deskriptif analitik dengan pendekatan cross sectional. Populasi seluruh tempat perindukan nyamuk yang potensial sebanyak 3 lokasi. Sampel sebanyak 3 lokasi dengan teknik purposive sampling. Pengambilan data menggunakan lembar observasi. Teknik analisis data menggunakan uji statistik pearson. Hasil penelitian lingkungan kimia tempat perindukan vektor malaria Anopheles spp di Desa Hanura memiliki rata - rata $\mathrm{pH}$ air 7,67, rata - rata salinitas air 3,47\%o, dan rata - rata oksigen terlarut (DO) $2,7 \mathrm{mg} / \mathrm{L}$. Lingkungan fisika tempat perindukan vektor malaria Anopheles spp di Desa Hanura memiliki rata - rata suhu air $28,25^{\circ} \mathrm{C}$ dan rata - rata kedalaman air $85 \mathrm{~cm}$. Lingkungan biologi tempat perindukan vektor malaria Anopheles spp di Desa Hanura dengan ditemukannya jenis tumbuhan bakau, lumut, kelapa dan jenis hewan ikan, kepiting, keong, udang dan kecebong. Kepadatan larva nyamuk Anopheles spp di Desa Hanura 10,08 ekor. Kesimpulan lingkungan kimia, fisika dan biologi berkorelasi dengan kepadatan larva nyamuk Anopheles spp di Desa Sukajaya Lempasing dengan $\mathrm{pH}$ air $(\mathrm{p}=0,031, r=-0,622)$, salinitas air $(p=0,085, r=0,517)$, kadar oksigen $(p=0,020, r=-0,657)$, suhu $(p=0,021, r=-0,655)$, kedalaman $(p=0,000, r=-0,872)$, tanaman $(p=0,000, r$ $=0,878)$ dan hewan $(p=0,056, r=-0,563)$. Disarankan masyarakat untuk pemberantasan tempat perkembang biakan nyamuk melalui penebaran bibit ikan pemakan jentik.

Kata Kunci : Ekologi, Perindukan, Vektor, Larva, Anopheles spp

\section{PENDAHULUAN}

Malaria adalah salah satu penyakit infeksi yang ditularkan oleh nyamuk Anopheles $s p$ betina. Nyamuk tersebut membawa parasit penyebab malaria, yaitu Plasmodium sp yang akan berkembang biak dalam sel darah merah manusia sehingga dapat mengakibatkan malaria. Penyakit ini dapat menginfeksi wanita maupun pria, terutama kelompok berisiko tinggi seperti bayi, balita, dan ibu hamil (Kemenkes RI, 2014).

World Malaria Report pada tahun 2015 menyebutkan bahwa malaria telah menyerang 106 negara di dunia. Komitmen global pada Millenium Development Goals (MDGs) menempatkan upaya pemberantasan malaria ke dalam salah satu tujuan bersama yang harus dicapai sampai dengan tahun 2015 melalui tujuan ketujuh yaitu memberantas penyakit HIV/AIDS, malaria, dan tuberkulosis. Dengan berakhirnya MDGs pada tahun 2015, komitmen global tersebut dilanjutkan melalui Sustainable Development Goals (SDGs). Pada SDGs, upaya pemberantasan malaria tertuang dalam tujuan ketiga yaitu menjamin kehidupan yang sehat dan mengupayakan kesejahteraan bagi semua orang, dengan tujuan spesifik yaitu mengakhiri epidemi AIDS, tuberkulosis, malaria, penyakit neglected-tropical sampai dengan tahun 2030 (Kemenkes RI, 2016).

Berdasarkan Profil Kesehatan Indonesia tahun 2017 diketahui bahwa secara nasional angka kesakitan malaria selama tahun 2009-2017 cenderung menurun yaitu dari 1,8 per 1.000 penduduk pada tahun 2009 menjadi 0,99 per 1.000 penduduk pada tahun 2017. Penduduk malaria di Provinsi Lampung berdasarkan Profil Kesehatan Provinsi Lampung sampai tahun 2017 menggunakan indikator API (Annual Parasite Incidence) dan AMI (Annual Malaria Incidence). Jika dilihat selama 7 tahun (2010-2017) terakhir angka AMI cenderung fluktuatif. AMI Provinsi Lampung tahun 2017 sebesar 2,42 per 1.000 penduduk, API di Provinsi Lampung tahun 2017 sebesar 0,52 per 1000 penduduk. Angka Kesakitan Malaria baik klinis (AMI) maupun pemeriksaan sedian darah di Kabupaten Kota pada tahun 2017 terlihat bahwa AMI tertinggi ada di Kabupaten Pesawaran dan Kota Bandar Lampung yaitu masing-masing 8,32 dan 8,21 dan API tertinggi ada di Kabupaten Pesawaran (Profil Dinas Kesehatan Provinsi Lampung, 2018).

Kabupaten Pesawaran mem yang berfluktuatif dalam rentanı 1 
5 tahun dari tahun 2011-2015. Pada tahun 2011 API kabupaten tersebut adalah 4,76 per 1000 penduduk, tahun 2012 adalah 1,00 per 1000 penduduk, tahun 2013 adalah 4,77 per 1000 penduduk, tahun 2014 mengalami peningkatan menjadi 7,26 per 1000 penduduk, dan menurun kembali di tahun 2015 menjadi 6,36 per 1000 penduduk. Tingginya angka API kabupaten tersebut membuat angka kejadian malaria juga tinggi (Dinas Kesehatan Kabupaten Pesawaran, 2016).

Berdasarkan Profil Kesehatan Kabupaten Pesawaran diketahui bahwa terdapat sebanyak 3.123 kasus malaria. Kasus positif malaria hanya terjadi di 3 wilayah kerja puskesmas yaitu Puskesmas Hanura (2.528 kasus), Puskesmas Pedada (147 kasus), dan Puskesmas Padang Cermin (448 kasus). Dan untuk 9 puskesmas lainnya bukan merupakan wilayah endemik malaria.

Kabupaten Pesawaran menjadi daerah yang endemis malaria karena kondisi alamnya. Kondisi alam Kabupaten Pesawaran disebut memungkinkan menjadi tempat untuk perkembangbiakan sekaligus perindukan nyamuk penyebab penyakit malaria. Hal ini disebabkan karena kabupaten tersebut memiliki daerah pesisir pantai, hutan dan tambak terlantar yang berpotensi menjadi tempat perindukannya (Dinas Kesehatan Kabupaten Pesawaran, 2016). Selain faktor perilaku, faktor hospes, dan faktor parasit, faktor yang paling sulit dikendalikan untuk mengurangi agent penyebab malaria saat ini adalah faktor lingkungan. Karena fungsi dari lingkungan dalam penyebaran penyakit malaria adalah sebagai breeding place nyamuk vektor (Babba, 2007).

Merujuk dari hasil penelitian Talan dan Mau (2016) di Kecamatan Kodi Balaghar Kabupaten Sumba Barat Daya selama delapan bulan dari bulan April November 2014. Habitat yang berpotensial sebagai tempat perkembangbiakan nyamuk yaitu genangan air, mata air, saluran air dan sungai kecil dengan suhu berkisar 21-35 ${ }^{\circ} \mathrm{C}$, pencahayaan 0,22-795 lux, $\mathrm{PH}$ berkisar antara 7,2-7,7, salinitas 0-0,1 $\%$ dengan ketinggian tempat berkisar antara 25-117 m/dpl. Dimana spesies Anopheles yang ditemukan pada habitat adalah An. vagus, An. barbirostris, dan An. annularis.

Lingkungan

yang dapat mengakibatkan terjadinya peningkatan angka kejadian malaria yaitu air tergenang, dan lingkungan kotor atau tidak sehat. Tempat-tempat tersebut sangat mempengaruhi perkembangbiakan vektor serta penyebaran kasus malaria (Santi, 2012). Berdasarkan latar belakang diatas peneliti tertarik untuk melakukan penelitian mengenai korelasi karakteristik ekologi tempat perindukan vektor malaria dengan kepadatan larva Anopheles spp. di Desa Hanura Kabupaten Pesawaran Tahun 2019.

\section{METODE}

Jenis penelitian ini merupakan survey analitik. Penelitian ini dilakukan pada tahun 2019 di Desa Hanura Kabupaten Pesawaran Provinsi Lampung setelah proposal disetujui. Penelitian ini dilaksanakan menggunakan metode survei, yaitu desain studi epidemiologi dengan rancangan penelitian cross sectional. Populasi yang digunakan dalam penelitian ini adalah semua habitat potensial larva Anopheles di Desa Hanura Kabupaten Pesawaran. Sampel adalah habitat potensial larva Anopheles yang terdapat di lokasi penelitian dengan radius $500 \mathrm{~m}$ dari rumah penderita malaria selama 1 tahun terakhir. Variabel independen dalam penelitian ini terdiri dari Lingkungan fisik (suhu air, oksigen terlarut (DO), kedalaman air) tempat perindukan vektor malaria. Lingkungan kimia ( $\mathrm{pH}$ dan salinitas air) tempat perindukan vektor malaria. Lingkungan biologi (tumbuhan air, hewan air). Variabel dependen Kepadatan larva Anopheles spp.

Analisis data bivariat digunakan untuk mengetahui interaksi dua variabel, baik berupa komparatif, asosiatif, maupun korelatif. Analisis bivariat pada penelitian ini adalah untuk mengetahui korelasi lingkungan fisik dan kimia (suhu air, kelembaban udara, kedalaman air, 
$\mathrm{pH}$, salinitas air) dengan kepadatan larva nyamuk Anopheles spp. Dalam penelitian ini digunakan Uji statistik spearman dengan bantuan program komputer SPSS 22,0 .

\section{HASIL}

1. Hasil Univariat Lingkungan Kimia Tempat Perindukan Vektor Malaria Anopheles spp

Tabel 1. Distribusi Lingkungan Kimia

\begin{tabular}{clccc}
\hline No & Tempat & pH air & Salinitas air & DO \\
\hline 1 & Tambak 1 & 8 & 4,4 & 2,58 \\
2 & Tambak 2 & 7 & 3,7 & 2,57 \\
3 & Tambak 3 & 8 & 2,7 & 2,61 \\
4 & Tambak 4 & 7 & 3,9 & 2,6 \\
5 & Lagun 1 & 7 & 4,2 & 2,73 \\
6 & Lagun 2 & 8 & 3,7 & 2,93 \\
7 & Lagun 3 & 7 & 4,2 & 2,52 \\
8 & Lagun 4 & 8 & 3,7 & 2,71 \\
9 & Selokan 1 & 8 & 2,8 & 2,77 \\
10 & Selokan 2 & 8 & 3 & 2,81 \\
11 & Selokan 3 & 8 & 2,4 & 2,79 \\
12 & Selokan 4 & 8 & 2,9 & 2,84 \\
\hline & Rata-rata & 7.67 & $3,47 \%$. & $2,7 \mathrm{mg} / \mathrm{L}$ \\
\hline
\end{tabular}

Berdasarkan tabel 1 dapat rata salinitas air sebesar 3,47\% dan diketahui bahwa rata-rata derajat rata-rata kadar oksigen sebesar 2,7 keasaman ( $\mathrm{pH}$ air) dari 12 tempat $\mathrm{mg} / \mathrm{L}$. pengambilan sampel sebesar 7,67 , rata-

\section{Hasil Univariat Lingkungan Fisik Tempat Perindukan Vektor Malaria} Anopheles spp.

Tabel 2. Distribusi Lingkungan Fisik

\begin{tabular}{clcc}
\hline No & Tempat & Suhu & $\begin{array}{l}\text { Kedalaman } \\
\text { Air }\end{array}$ \\
\hline 1 & Tambak 1 & 27 & 76 \\
2 & Tambak 2 & 27 & 47 \\
3 & Tambak 3 & 30 & 100 \\
4 & Tambak 4 & 28 & 99 \\
5 & Lagun 1 & 28 & 54 \\
6 & Lagun 2 & 29 & 100 \\
7 & Lagun 3 & 27 & 65 \\
8 & Lagun 4 & 30 & 101 \\
9 & Selokan 1 & 27 & 90 \\
10 & Selokan 2 & 28 & 97 \\
11 & Selokan 3 & 29 & 95 \\
12 & Selokan 4 & 27 & 96 \\
\hline & Rata-rata & $28,25^{\circ} \mathrm{C}$ & $85 \mathrm{~cm}$ \\
\hline
\end{tabular}

Berdasarkan tabel 2 dapat

$28,25^{\circ} \mathrm{C}$, rata-rata diketahui bahwa rata-rata suhu air dari kedalaman air $85 \mathrm{~cm}$. 12 tempat pengambilan sampel sebesar 


\section{Hasil Univariat Lingkungan Biologi Tempat Perindukan Vektor Malaria Anopheles spp}

\section{Tumbuhan air}

Tabel 3. Distribusi Tumbuhan Air

\begin{tabular}{|c|c|c|c|c|}
\hline No & Tempat & $\begin{array}{l}\text { Tidak } \\
\text { Ada }\end{array}$ & Ada & Nama Tumbuhan \\
\hline 1 & Tambak 1 & & $\sqrt{ }$ & Bakau, Lumut \\
\hline 2 & Tambak 2 & & $\sqrt{ }$ & Bakau, Lumut \\
\hline 3 & Tambak 3 & $\sqrt{ }$ & & Tidak Ada \\
\hline 4 & Tambak 4 & & $\sqrt{ }$ & Bakau, Lumut \\
\hline 5 & Lagun 1 & & $\sqrt{ }$ & Bakau, Lumut \\
\hline 6 & Lagun 2 & $\sqrt{ }$ & & Tidak Ada \\
\hline 7 & Lagun 3 & & $\sqrt{ }$ & Bakau, Lumut \\
\hline 8 & Lagun 4 & & $\sqrt{ }$ & Kelapa \\
\hline 9 & Selokan 1 & $\sqrt{ }$ & & Tidak Ada \\
\hline 10 & Selokan 2 & & $\sqrt{ }$ & Bakau \\
\hline 11 & Selokan 3 & & $\sqrt{ }$ & Lumut \\
\hline 12 & Selokan 4 & $\sqrt{ }$ & & Tidak Ada \\
\hline & Total & $\begin{array}{c}4 \\
(33,3 \%)\end{array}$ & $\begin{array}{l}8 \\
6,7 \%)\end{array}$ & \\
\hline
\end{tabular}

Berdasarkan tabel 3 dapat $(75,0 \%)$ yang terdapat tumbuhan, di diketahui bahwa di tambak terdapat 3 selokan terdapat 2 selokan $(50,0 \%)$ tambak $(75.0 \%)$ yang terdapat yang terdapat tumbuhan, yaitu bakau, tumbuhan, di lagun terdapat 3 lagun lumut, dan kelapa.

2. Hewan

\begin{tabular}{|c|c|c|c|c|}
\hline No & Tempat & $\begin{array}{l}\text { Tidak } \\
\text { Ada }\end{array}$ & Ada & Nama Tumbuhan \\
\hline 1 & Tambak 1 & \multirow{4}{*}{$\sqrt{ }$} & $\sqrt{ }$ & Kepiting \\
\hline 2 & Tambak 2 & & & Tidak Ada \\
\hline 3 & Tambak 3 & & $\sqrt{ }$ & Keong \\
\hline 4 & Tambak 4 & & $\sqrt{ }$ & Udang \\
\hline 5 & Lagun 1 & \multirow{4}{*}{$\sqrt{ }$} & $\sqrt{ }$ & Ikan, Kecebong \\
\hline 6 & Lagun 2 & & $\sqrt{ }$ & Keong \\
\hline 7 & Lagun 3 & & & Tidak Ada \\
\hline 8 & Lagun 4 & & $\sqrt{ }$ & Ikan, Keong \\
\hline 9 & Selokan 1 & \multirow[t]{4}{*}{$\sqrt{ }$} & & Tidak Ada \\
\hline 10 & Selokan 2 & & $\sqrt{ }$ & Keong \\
\hline 11 & Selokan 3 & & $\sqrt{ }$ & Keong dan Kepiting \\
\hline 12 & Selokan 4 & & $\sqrt{ }$ & Ikan \\
\hline & Total & $\begin{array}{c}3 \\
(16,7 \%)\end{array}$ & $\begin{array}{c}9 \\
(83,3 \%)\end{array}$ & \\
\hline
\end{tabular}

Berdasarkan tabel 4. dapat terdapat hewan, di selokan terdapat 3 diketahui bahwa di tambak terdapat 3 selokan $(75,0 \%)$ yang terdapat hewan tambak $(75.0 \%)$ yang terdapat hewan, yaitu ikan, kepiting, keong, udang dan di lagun terdapat 3 lagun $(75,0 \%)$ yang kecebong. 


\section{Hasil Univariat Kepadatan Larva Nyamuk Anopheles spp}

\begin{tabular}{|c|c|c|c|}
\hline No & Tempat & $\begin{array}{l}\text { Kepadatan } \\
\text { Larva }\end{array}$ & Mean \\
\hline 1 & Tambak 1 & 13 & \\
\hline 2 & Tambak 2 & 14 & \\
\hline 3 & Tambak 3 & 9 & 11,5 \\
\hline 4 & Tambak 4 & 10 & \\
\hline 5 & Lagun 1 & 12 & \\
\hline 6 & Lagun 2 & 8 & 9,75 \\
\hline 7 & Lagun 3 & 12 & \\
\hline 8 & Lagun 4 & 7 & \\
\hline 9 & Selokan 1 & 11 & \\
\hline 10 & Selokan 2 & 8 & 9,00 \\
\hline 11 & Selokan 3 & 9 & \\
\hline 12 & Selokan 4 & 8 & \\
\hline
\end{tabular}

Berdasarkan tabel 5. dapat di tambak sebesar 11,5, di lagun 9,75, di diketahui bahwa rata-rata kepadatan selokan 9,0, dan rata-rata keseluruhan larva pada tempat pengambilan sampel kepadatan larva 10,08.

\section{Hasil Bivariat Korelasi Lingkungan Kimia, Fisika dan Biologi Dengan Kepadatan Larva Nyamuk Anopheles spp}

\section{Uji Korelasi Lingkungan Kimia dengan Kepadatan Larva Nyamuk Anopheles spp}

Tabel 6. Korelasi Lingkungan Kimia dengan Kepadatan Larva Nyamuk Anopheles spp

\begin{tabular}{|c|c|c|}
\hline $\begin{array}{l}\text { Lingkungan } \\
\text { Kimia }\end{array}$ & Nilai $r$ & p-value \\
\hline a. $\mathrm{pH}$ air & -0.622 & 0.031 \\
\hline $\begin{array}{l}\text { b. Salinitas air } \\
(\% 0)\end{array}$ & 0.517 & 0.085 \\
\hline c. Kadar oksigen & -0.657 & 0.020 \\
\hline
\end{tabular}

Dari Tabel 6. di atas dapat dilihat bahwa hasil analisis korelasi menunjukkan bahwa $\mathrm{pH}$ berkorelasi negatif terhadap kepadatan dengan nilai korelasi ( $r$ ) adalah $-0,622$ yang berarti semakin rendah nilai $\mathrm{pH}$ maka semakin tinggi kepadatan larvanya. Salinitas berkorelasi positif terhadap kepadatan dengan nilai korelasi ( $r$ ) adalah 0,517 yang berarti semakin rendah salinitas maka semakin rendah kepadatan larva di tempat perindukan. DO berkorelasi negatif terhadap kepadatan larva dengan nilai korelasi $(r)$ adalah $-0,657$ yang berarti bahwa semakin rendah DO maka semakin tinggi kepadatan larva di tempat perindukan. 


\section{Uji Korelasi Lingkungan Fisika dengan kepadatan larva nyamuk Anopheles spp}

Tabel 7. Korelasi Lingkungan Fisik dengan Kepadatan Larva Nyamuk
\begin{tabular}{llc} 
Anopheles spp \\
\hline Lingkungan Fisika & Nilai r & p-value \\
\hline a. Suhu air $\left({ }^{\circ} \mathrm{C}\right)$ & -0.655 & 0.021 \\
b. Kedalaman air $(\mathrm{cm})$ & -0.872 & 0.000 \\
\hline
\end{tabular}

Dari Tabel 7. di atas dapat dilihat bahwa hasil analisis korelasi menunjukkan bahwa suhu berkorelasi negatif terhadap kepadatan dengan nilai korelasi ( $r$ ) adalah $-0,655$ yang berarti semakin rendah suhu maka semakin tinggi kepadatan larva di tempat perindukan, dan kedalaman berkorelasi negatif terhadap kepadatan larva dengan nilai korelasi $(r)$ adalah $-0,872$ yang berarti semakin rendah tingkat kedalaman maka semakin tinggi pula kepadatan larvanya.

\section{Uji Korelasi Lingkungan Biologi dengan kepadatan Larva Nyamuk Anopheles spp}

Tabel 8. Korelasi Lingkungan Biologi dengan Kepadatan Larva Nyamuk Anopheles spp

\begin{tabular}{ccc}
\hline $\begin{array}{l}\text { Lingkungan } \\
\text { Biologi }\end{array}$ & Nilai $\mathbf{r}$ & p-value \\
\hline Tumbuhan & 0.878 & 0.000 \\
Hewan & -0.563 & 0.056 \\
\hline
\end{tabular}

Tumbuhan berkorelasi positif terhadap kepadatan dengan nilai korelasi (r) adalah 0,878 yang berarti semakin banyak tumbuhan maka semakin tinggi kepadatan larva di tempat perindukan. Dan hewan berkorelasi negatif terhadap

\section{PEMBAHASAN}

\section{Kepadatan Larva}

Hasil penelitian menunjukkan rata-rata kepadatan larva pada tempat pengambilan sampel di tambak sebesar 11,5 , di lagun 9,75, di selokan 9,0, dan rata-rata keseluruhan kepadatan larva 10,08 .

Cara penangkapan dilakukan dengan pencidukan menggunakan dipper standar WHO. Kepadatan larva Anopheles paling banyak ditemukan pada bagian barat dan ditemukan pada semua lokasi pengambilan. $\mathrm{Hal}$ ini berhubungan dengan adanya tempat perkembangbiakan larva Anopheles tersebut yakni tambak dan sawah dengan tanaman air di sekitarnya berupa lumut, alga dan hydrilla yang merupakan makanan bagi larva itu sendiri. kepadatan dengan nilai korelasi ( $r$ ) adalah -0,563 yang berarti semakin banyak hewan predator maka semakin rendah kepadatan larva di tempat perindukan.

Desa Hanura yang merupakan wilayah dengan kondisi dataran rendah, air tanah dangkal, bila terjadi hujan sedikit bisa menambah genangan air, ini berpeluang menjadi breeding site yang memungkinkan berkembangbiaknya larva Anopheles.

Suatu breeding site dapat berperan dalam peningkatan populasi nyamuk dan densitas larva pada suatu daerah tergantung dari kondisi lingkungan baik lingkungan biotik, abiotik, maupun lingkungan sosial dan keadaan geografis serta topografi daerah setempat. Hal ini tergambar pada Desa Hanura telah dijelaskan diatas bahwa merupakan daerah yang berpotensi sebagai tempat berkembangbiaknya vektor malaria dilihat dari segi topografi yang merupakan dataran rendah serta 
memiliki air tanah dangkal yang memberikan peluang bila hujan akan tergenang air sebagai breeding site nyamuk Anopheles.

Berdasarkan uraian diatas dapat disimpulkan bahwa terjadinya peningkatan populasi densitas larva maupun nyamuk dewasa sangatlah didukung oleh kondisi lingkungan, keadaan geografis, topografi serta ketinggian tempat suatu daerah yang memberikan kemungkinan terjadinya peningkatan kasus malaria pada daerah tersebut.

\section{Lingkungan Kimia}

a. $\mathrm{pH}$ air

Berdasarkan tabel 1 dapat diketahui bahwa rata-rata derajat keasaman ( $\mathrm{pH}$ air) sebesar 7,67. Hal ini menunjukkan bahwa $\mathrm{pH}$ air sampel dalam kisaran normal. Angka $\mathrm{pH}$ air laut berkisar dari 7,4 hingga 8,3, berarti sedikit bersifat basa.

Nilai pH dalam suatu perairan dipengaruhi oleh beberapa faktor antara lain kegiatan fotosintesis, suhu dan terdapatnya anion dan kation. Pada umumnya $\mathrm{pH}$ perairan laut lebih stabil, namun di perairan pinggir pantai, nilai $\mathrm{pH}$ ditentukan oleh kuantitas bahan organik yang masuk ke perairan tersebut. Toksisitas dan daya racun dalam perairan dipengaruhi oleh tinggi rendahnya $\mathrm{pH}$. Perubahan nilai $\mathrm{pH}$ perairan pesisir (laut) yang kecil saja dari nilai alaminya menunjukkan sistem penyangga perairan tersebut terganggu, sebab sebenarnya air laut mempunyai kemampuan untuk mencegah perubahan $\mathrm{pH}$. Derajat keasaman $\mathrm{pH}$ air akan sangat menentukan aktivitas mikroorganisme, pada $\mathrm{pH}$ antara 6,5 - 8,3 aktivitas mikroorganisme sangat baik. Pada $\mathrm{pH}$ yang sangat kecil atau sangat besar, mikroorganisme tidak aktif, atau bahkan akan mati (Pamungkas, 2016).

Berdasarkan hasil dari pengolahan data maka dapat diketahui bahwa faktor abiotik $\mathrm{pH}$ air tempat perindukan vektor malaria
Anopheles spp di Desa Hanura Kabupaten Pesawaran Provinsi Lampung, rata-rata $\mathrm{pH}$ air sebesar 7,6. Hasil uji korelasi menunjukkan $\mathrm{pH}$ berkorelasi negatif terhadap kepadatan dengan nilai korelasi $(r)$ adalah $-0,779$ yang berarti semakin rendah nilai $\mathrm{pH}$ maka semakin tinggi kepadatan larvanya.

Hasil penelitian ini sejalan dengan penelitian Effendi (2003), bahwa sebagian besar biota akuatik menyukai nilai pH antara 7-8,5. Menurut Syarif (2003) larva Anopheles spp memiliki toleransi terhadap pH antara 7,91-8,09. Raharjo, dkk (2003) juga menyatakan bahwa $\mathrm{pH}$ tempat perindukan nyamuk Anopheles spp pada musim kemarau berkisar antara $6,8-8,6$.

Berdasarkan hal tersebut peneliti berpendapat bahwa faktor $\mathrm{pH}$ air mempengaruhi tingkat kesuburan perairan karena mempengaruhi jasad renik. Perairan asam kurang baik untuk perkembangbiakan bahkan cenderung mematikan organisme. Hal ini disebabkan oleh spesies nyamuk yang dapat hidup pada $\mathrm{pH}$ yang berbeda misalnya An. letifer bisa bertahan hidup di lingkungan air tawar ( $\mathrm{pH}$ normal). Nilai $\mathrm{pH}$ sangat berpengaruh terhadap proses biokimia perairan, misalnya proses nitrifikasi akan berakhir jika $\mathrm{pH}$ rendah. Pada ketiga tambak nilai $\mathrm{pH}$ normal cenderung basa sehingga cukup ideal dalam perkembangan larva Anopheles spp.

\section{b. Salinitas air}

Berdasarkan tabel 1 dapat diketahui bahwa rata-rata salinitas air sebesar 3,47\%o. Hal ini sejalan teori bahwa perairan muara sungai dan estuaria biasanya mempunyai salinitas lebih rendah dari air laut normal dan disebut sebagai perairan payau (brackish water). Batas pergoyangan air payau ini berkisar $0,5 \%$ sampai dengan $30 \%$.

Setelah dilakukan data maka diketahui bahwa salinitas air tempat perindukan vektor malaria Anopheles 
spp di Desa Hanura Kabupaten Pesawaran Provinsi Lampung, ratarata salinitas air sebesar 3,28 (\%o). Hasil uji korelasi menunjukkan salinitas berkorelasi positif terhadap kepadatan dengan nilai korelasi $(r)$ adalah 0,647 yang berarti semakin rendah salinitas maka semakin rendah kepadatan larva di tempat perindukan. Anopheles sundaicus dapat berkembang dengan baik pada salinitas antara 4-30 \%o. Beberapa jenis Anopheles spp mampu menyesuaikan diri dan hidup dalam kondisi air yang payau serta larva tidak dapat bertahan hidup pada kadar garam diatas $40 \%$ akan mengalami kematian, larva toleran terhadap salinitas antara $12 \%-18 \%$.

Berdasarkan kemampuannya untuk menyesuaikan diri terhadap salinitas, organisme perairan dapat digolongkan menjadi stenohaline dan euryhaline. Stenohaline merupakan organisme perairan yang mempunyai kisaran kemampuan untuk menyesuaikan diri terhadap salinitas sempit, sedangkan euryhaline merupakan organisme perairan yang mempunyai kisaran kemampuan untuk menyesuaikan diri terhadap salinitas yang lebar (Odum, 1998).

Hasil penelitian ini sejalan dengan penelitian Sugiarti, dkk (2020) yang dilakukan di wilayah kerja Puskesmas Hanura Kabupaten Pesawaran menunjukkan nilai salinitas 0-9,3. Hal ini disebabkan pengambilan sampel masih dilakukan di wilayah yang sama dengan penelitian sebelumnya, hanya pada waktu yang berbeda.

c. Oksigen terlarut (DO)

Berdasarkan tabel 1 dapat diketahui bahwa rata-rata kadar oksigen sebesar 2,7 mg/L. Kondisi oksigen terlarut pada perairan tempat larva nyamuk hidup masih baik yaitu lebih dari $2 \mathrm{mg} / \mathrm{l}$. Hasil uji korelasi menunjukkan DO berkorelasi negatif terhadap kepadatan larva dengan nilai korelasi ( $r$ ) adalah $-0,667$ yang berarti bahwa semakin rendah DO maka semakin tinggi kepadatan larva di tempat perindukan.
Oksigen terlarut dapat berasal dari difusi oksigen yang terdapat di atmosfer dan aktivitas fotosintesis oleh tumbuhan air. Menurut UNESCO/WHO/UNEP (1992) dalam Effendi (2003) kadar DO optimum yang baik untuk menopang kehidupan organisme akuatik berkisar antara 2,0 $9,0 \mathrm{mg} / \mathrm{l}$. Ketiga tempat perindukan mempunyai kadar oksigen terlarut yang lebih dari $2 \mathrm{mg} / \mathrm{l}$, hal tersebut menunjukkan bahwa proses fotosintesis yang dilakukan oleh produsen (tumbuh-tumbuhan yang berada di sekitar tempat perindukan nyamuk) berjalan dengan baik, karena sumber oksigen terlarut terdapat pada perairan adalah berasal dari proses fotosintesis. Hal ini menunjukkan bahwa Desa Hanura Kabupaten Pesawaran Provinsi Lampung merupakan tempat perindukan yang baik untuk vektor malaria Anopheles spp karena memiliki kadar oksigen terlarut yang baik untuk menopang kehidupan organisme akuatik.

\section{Lingkungan Fisika}

a. Suhu air

Berdasarkan tabel 2 dapat diketahui bahwa rata-rata suhu air sebesar $28,25^{\circ} \mathrm{C}$ Hasil dari pengolahan data maka dapat diketahui bahwa faktor abiotik suhu air tempat perindukan vektor malaria Anopheles spp di Desa Hanura Kabupaten Pesawaran Provinsi Lampung, rata-rata suhu air sebesar $27,81^{\circ} \mathrm{C}$. Hasil uji korelasi menunjukkan suhu berkorelasi negatif terhadap kepadatan dengan nilai korelasi $(r)$ adalah $-0,780$ yang berarti semakin rendah suhu maka semakin tinggi kepadatan larva di tempat perindukan.

Hasil penelitian ini sesuai dengan teori yang menyatakan suhu mempengaruhi perkembangan parasit dalam nyamuk. Suhu yang optimum berkisar antara $20-30^{\circ} \mathrm{C}$. Makin tinggi suhu (sampai batas tertentu) makin pendek masa inkubasi ekstrinsik (sporogoni) dan sebaliknya makin rendah suhu makin 
panjang masa inkubasi ekstrinsik. Pengaruh suhu ini berbeda bagi setiap spesies, pada suhu $26,7^{\circ} \mathrm{C}$ masa inkubasi ekstrinsik adalah 1012 hari untuk $P$. falciparum dan 8-11 hari untuk $P$. vivax, $14-15$ hari untuk P. malariae dan $P$. ovale (Widoyono, 2011).

Nyamuk dapat bertahan hidup pada suhu rendah namun proses metabolismenya menurun bahkan terhenti bila suhu turun sampai suhu kritis dan pada suhu yang sangat tinggi akan mengalami perubahan proses fisiologisnya. Suhu optimum untuk pertumbuhan nyamuk adalah $25^{\circ}-27^{\circ} \mathrm{C}$. Toleransi suhu bergantung pada jenis nyamuknya, biasanya pada suhu $5^{0}-6^{\circ} \mathrm{C}$ spesies nyamuk tidak dapat bertahan hidup. Pertumbuhan nyamuk akan terhenti sama sekali bila suhu kurang dari $10^{\circ} \mathrm{C}$ atau lebih dari $40^{\circ} \mathrm{C}$ (Kemenkes RI, 2014).

Berdasarkan hal tersebut peneliti berpendapat bahwa suhu mempengaruhi kadar $\mathrm{CO}_{2}$ yang terlarut dalam air yang diperoleh tiap organisme akan bervariasi dan berkaitan dengan pertumbuhan, metabolisme, dan respirasi. Apabila terjadi peningkatan suhu disertai tingginya karbondioksida menyebabkan keberadaan oksigen tidak mampu memenuhi kebutuhan organisme akuatik untuk melakukan proses metabolisme dan respirasi.

b. Kedalaman air

Berdasarkan tabel 2 dapat diketahui bahwa rata-rata kedalaman air sebesar $85 \mathrm{~cm}$. Hasil dari pengolahan data maka dapat diketahui bahwa faktor abiotik kedalaman air tempat perindukan vektor malaria Anopheles spp di Desa Hanura Kabupaten Pesawaran Provinsi Lampung, rata - rata kedalaman air sebesar $81,67 \mathrm{~cm}$. Hasil uji korelasi menunjukkan kedalaman berkorelasi negatif terhadap kepadatan larva dengan nilai korelasi ( $r$ ) adalah $-0,882$ yang berarti semakin rendah tingkat kedalaman maka semakin tinggi pula kepadatan larvanya.

Hal ini sesuai dengan teori Kemenkes RI (2014) larva Anopheles spp hanya mampu berenang ke bawah permukaan air paling dalam 1 meter dan tingkat volume air akan dipengaruhi curah hujan yang cukup tinggi yang akan memperbesar kesempatan nyamuk untuk berkembang biak secara optimal pada kedalaman kurang dari 3 meter. Dari hasil tersebut dapat disimpulkan bahwa yaitu kedalaman air tinggi maka kepadatan larva tinggi. Hal ini sesuai dengan pendapat Syarief (2003) bahwa semakin dalam tempat perindukan maka kepadatan larva semakin meningkat, karena larva akan bergerak bebas dengan berkurangnya jumlah ikan predator yang memangsanya. Menurut peneliti kedalaman air mendukung perkembangan larva nyamuk Anopheles spp karena banyaknya volume air yang terdapat pada tempat perindukan. Volume air akan mempengaruhi jumlah tempat perkembangan larva (breeding place).

\section{Lingkungan Biologi}

a. Tumbuhan

Berdasarkan tabel 3 dapat diketahui bahwa terdapat 3 tambak $(75.0 \%)$ yang terdapat tumbuhan, di lagun terdapat 2 lagun $(50,0 \%)$ yang terdapat tumbuhan, di selokan terdapat 2 selokan $(50,0 \%)$ yang terdapat tumbuhan, yaitu bakau, lumut, dan kelapa. Hasil uji korelasi menunjukkan tumbuhan berkorelasi positif terhadap kepadatan dengan nilai korelasi $(r)$ adalah 0,878 yang berarti semakin banyak tumbuhan maka semakin tinggi kepadatan larva di tempat perindukan. Jenis tumbuhan yang ada disekitar lokasi tambak yaitu tumbuhan bakau dan lumut, pada lokasi selokan terdapat tumbuhan semak-semak dan lumut sedangkan pada lagun terdapat tumbuhan pohon kelapa.

Hasil penelitian ini didukung dengan penelitian yang dilakukan 
Septiani, dkk (2012) tentang hubungan faktor abiotik dengan kepadatan larva dan kondisi ekologi tempat perindukan vektor (tambak terlantar) di Desa Sukamaju Kecamatan Punduh Pedada Kabupaten Pesawaran Lampung, Pengamatan faktor biologi ditemukan jenis tumbuhan air berupa ganggang dan lumut serta hewan air berupa kepiting (Uca pugnax), udang (Palaemonete $s p$ ), kecebong (Rana sp.), dan bentos.

Tumbuhan yang ditemukan di sekitar tempat perindukan larva nyamuk Anopheles sp. Pada ketiga rawa adalah tumbuhan berkayu yaitu pohon kelapa (Cocos nucifera), sedangkan tumbuhan airnya berupa alga, dan kangkung. Menurut Depkes RI (2004), adanya tumbuhtumbuhan sangat mempengaruhi kehidupan nyamuk antara lain: sebagai tempat meletakkan telur, tempat berlindung, tempat mencari makan dan berlindung bagi larva dan tempat hinggap istirahat nyamuk dewasa selama menunggu siklus gonotropik.

An. sundaicus akan meletakkan telur di sekitar alga hijau yang terdapat jasad renik, sehingga begitu menetas, larvanya dapat memperoleh asupan makanan secara langsung dari renik hidup (Septiani dkk, 2012). Adanya tumbuhan di sekitar perairan akan mempengaruhi keberadaan oksigen yang dibutuhkan oleh biota perairan tersebut untuk hidup. Oksigen adalah salah satu gas yang ditemukan terlarut pada perairan. Sumber oksigen terlarut berasal dari difusi oksigen yang terdapat di atmosfer dan aktivitas fotosintesis oleh tumbuhan air dan fitoplankton (Effendi, 2003). Menurut pendapat peneliti adanya tumbuhan di perairan merupakan tempat yang baik untuk perindukan larva Anopheles spp., karena keberadaan tumbuhan air di sekitar perindukan digunakan oleh larva sebagai tempat berlindung. b. Hewan

Berdasarkan tabel 4 dapat diketahui bahwa di tambak terdapat 3 tambak $(75.0 \%)$ yang terdapat hewan, di lagun terdapat 1 lagun $(25,0 \%)$ yang terdapat hewan, di selokan terdapat 3 selokan $(75,0 \%)$ yang terdapat hewan yaitu ikan, kepiting, keong, udang dan kecebong Hasil uji korelasi menunjukkan hewan berkorelasi negatif terhadap kepadatan dengan nilai korelasi ( $r$ ) adalah $-0,563$ yang berarti semakin banyak hewan predator maka semakin rendah kepadatan larva di tempat perindukan.

Jenis hewan yang ada di lokasi tambak yaitu keong, udang dan kepiting sedangkan pada lokasi selokan terdapat kecebong dan lokasi lagun terdapat hewan jenis keong. Pemangsaan berperan penting dalam komunitas akuatik secara langsung dengan mengurangi kelimpahan mangsanya dan tidak langsung dengan mengubah keragaman mangsa dan interaksi antar spesies (Alto dkk, 2005). Berdasarkan pendapat Odum (1998) dalam ekosistem ada rantai makanan dan jaring makanan pada konsep keseimbangan. Sebagai konsumen primer, larva nyamuk akan dimakan oleh konsumen sekunder seperti ikan dan ikan akan dimakan oleh konsumen berikutnya atau mati dan diuraikan oleh dekomposer. Keseimbangan akan terganggu bila rantai makanan atau jaring makanan terputus.

Keberadaan ikan pada tempat perindukan mempengaruhi larva nyamuk, makin banyak ikan maka kepadatan larva semakin kecil dan makin sedikit ikan maka kepadatan larva semakin besar. Menurut peneliti keberadaan hewan akuatik dapat berpotensi menjadi musuh alami (predator) yang dapat mengurangi jumlah populasi larva nyamuk di tempat perindukan.

\section{KESIMPULAN}

Faktor tempat perindukan vektor malaria Anopheles spp di Desa Hanura 
diketahui $\mathrm{pH}$ air 7,67, salinitas air $3,47 \%$ o, dan oksigen terlarut (DO) $2,7 \mathrm{mg} / \mathrm{L}$ (lingkungan kimia), suhu air $28,25^{\circ} \mathrm{C}$ dan kedalaman air $85 \mathrm{~cm}$ (lingkungan fisika).

Lingkungan biologi tempat perindukan vektor malaria Anopheles spp di Desa Hanura dengan ditemukannya jenis tumbuhan bakau, lumut, kelapa dan jenis hewan ikan, kepiting, keong, udang dan kecebong dan rata-rata kepadatan larva Anopheles spp di Desa Hanura 10,08.

Lingkungan kimia, fisika dan biologi berkorelasi dengan kepadatan larva nyamuk Anopheles spp di Desa Hanura dengan $\mathrm{pH}$ air $(p=0,031, r=-0,622)$, salinitas air $(p=0,085, r=0,517)$, kadar oksigen $(p=0,020, r=-0,657)$, suhu $(p=0,021, r=-0,655)$, kedalaman $(p=$ $0,000, r=-0,872)$, tanaman $(p=0,000$, $r=0,878)$ dan hewan $(p=0,056, r=-$ $0,563)$.

\section{SARAN}

Diharapkan aparat desa serta petugas pelaksana program malaria untuk dapat meningkatkan upaya promotif bagi masyarakat melalui penyuluhan kesehatan yang bertujuan meningkatkan kesadaran masyarakat dalam upaya menurunkan mata rantai penularan malaria. Seperti membersihkan daerah tambak dan selokan dari tumbuhan air, menyebar ikan predator.

Melakukan upaya untuk mengurangi kepadatan larva Anopheles spp. dengan membersihkan daerah tambak dan selokan dari tumbuhan air, menyebar predator seperti ikan predator di sekitar selokan.

Diharapkan dengan penelitian ini dapat menjadi tambahan informasi dan pengembangan penelitian berikutnya dan untuk melanjutkan penelitian menggunakan sampel yang lebih besar dan area pengambilan sampel yang lebih luas, sehingga mendapatkan perbandingan kepadatan larva.

\section{DAFTAR PUSTAKA}

Alto, B.W., Griswold, M.W., \& Lounibos, L.P. (2005). Habitat Complexity and Sex-
Dependent Predation of Mosquito Larvae in Containers. Oecologia 146 (2):300-310.

Babba, I. (2007). Faktor-Faktor Risiko yang Mempengaruhi Kejadian Malaria (Studi kasus di Wilayah Kerja Puskesmas Hamadi Kota Jayapura). [Tesis]. Semarang: Universitas Diponegoro.

Depkes RI. (2004). Pedoman Ekologi dan Aspek Perilaku Vektor. Jakarta : Direktorat Jenderal Pemberantasan Penyakit Menular dan Penyehatan Lingkungan Pemukiman

Dinas Kesehatan Provinsi Lampung. (2012). Profil Kesehatan Provinsi Lampung. Bandar Lampung: Dinas Kesehatan Provinsi Lampung.

Dinas Kesehatan Kabupaten Pesawaran. (2016). Profil Kesehatan Kabupaten Pesawaran. Bandar Lampung: Dinas Kesehatan Kabupaten Pesawaran.

Effendi, H. (2003). Telaah Kualitas Air Bagi Pengelolaan Sumber Daya dan Lingkungan Perairan. Yogyakarta: Kanisius.

Kementerian Kesehatan Republik Indonesia. (2014). Pedoman Teknis Pemeriksaan Parasit Malaria. Jakarta: Kementerian Kesehatan Republik Indonesia.

Kementerian Kesehatan Republik Indonesia. (2016). Infodatin Malaria.

www.depkes.go.id/download.php ?file.

Kementerian Kesehatan Republik Indonesia. (2016). Malaria 2016. www.depkes.go.id/download.php ?file.

Kementerian Kesehatan Republik Indonesia. (2016). Modul Peningkatan Kemampuan Teknis Mikroskopis Malaria. Jakarta: Kementerian Kesehatan Republik Indonesia.

Odum, E.P. (1998). Dasar-Dasar Ekologi Edisi ke-3. Yogyakarta: UGMPress.

Pamungkas, M.O.A. (2016). Studi Pencemaran Limbah Cair dengan Parameter BOD5 dan $\mathrm{pH}$ di Pasar 
Ikan Tradisional dan Pasar Modern di Kota Semarang. Jurnal Kesehatan Masyarakat (Undip) 4 (2): 166-175.

Profil Dinas Kesehatan Provinsi Lampung. (2018).

Raharjo, M., Sutikno, S.J. \& Mardihusodo. (2003). Karakteristik Wilayah Sebagai Determinan Sebaran Anopheles aconitus di Kabupaten Jepara. First Congress of Indonesia Mosquito Control Association in the Commeration of Mosquito Day. Prosiding, Yogyakarta.

Santi, M. (2012). Faktor-faktor yang berpengaruh dengan kejadian malaria pada penduduk Kecamatan Lengkong Kabupaten Sukabumi yang pernah bermigrasi tahun 2011. [Skripsi]. Depok: Universitas Indonesia

Septiani, L., Setyaningrum, E., \& Ernawati, K. (2013). Studi Ekologi Tempat Perindukan Vektor Malaria Di Desa Sukamaju Kecamatan Punduh Pedada Kabupaten Pesawaran Propinsi Lampung. In Prosiding Seminar Nasional Sains Mipa dan Aplikasi (ISBN: 978-602-98559-1-3), 3(3).

Sugiarti, S., Wahyudo, R., Kurniawan, B., \& Suwandi, J.F. (2020). The Physical, Chemical, and Biological Characteristics of Anopheles sp, a Potential Breeding Place in Puskesmas Hanura Working Area. Medula 10 (2): 272-277.

Syarif, H. S. (2003). Studi Ekologi Perindukan Nyamuk Vektor Penyakit Malaria di Desa Sukajaya Lempasing Kec. Padang Cermin Lampung Selatan. [Skripsi]. Bandar Lampung: Universitas Lampung.

Tallan, M. M., \& Mau, F. (2016). Karakteristik Habitat Perkembangbiakan Vektor Filariasis di Kecamatan Kodi Balaghar Kabupaten Sumba Barat Daya. ASPIRATOR- Jurnal Penelitian Penyakit Tular Vektor (Journal of Vector-borne Diseases Studies) 8(2): 55-62.
Widoyono. (2011). Penyakit Tropis Epidemiologi, Penularan, Pencegahan dan Pemberantasannya. Edisi Kedua. Jakarta: Erlangga. 